DOI

\title{
ОБГРУНТУВАННЯПАРАМЕТРІВ ПРОЦЕСУ СУШІННЯ НАСІННЯ СОНЯШНИКУ У ВІБРОСУШАРЦ НА ОСНОВІ ІНФРАЧЕРВОНОГО ОПРОМІНЕННЯ
}

\author{
Бандура В.М. к.т.н., професор, Ярошенко Л.В. к.т.н., доцент
}

Вінницький національний аграрний університет, м. Вінниця

\begin{abstract}
Анотація. Одним із перспективних напрямів розвитку харчової промисловості є розширення асортименту і підвищення якості продуктів харчування. При цььому особливу увагу приділяють безпечності i якості сировини. Насіння соняшнику є повноцінною сировиною для отримання ряду харчових і кормових продуктів.

У системі технологічних операиій післязбиральної обробки соняшнику найважливіше місце належить сушінню. Якісне сушіння не тільки забезпечує зберігання зібраного урожаю, запобігає його втратам, але у деяких випадках і підвищує якість готового продукту.

В роботі описані технологічні особливості сушіння насіння соняшнику за допомогою інфрачервоного підведення енергії, та обтрунтовано перспективність вібраційного моношарного сушіння насіння соняшнику в лотковій вібросушариі. Визначені питомі затрати енергї на процес інфрачервоного сушіння продукту.

Ключові слова: інфрачервоне сушіння, вібролоткова сушарка, насіння соняшнику, енергія.
\end{abstract}

\section{RATIONALE OF PARAMETERS OF THE PROCESS OF DRYING SUNFLOWER GREEN IN THE VIBROUSUSCARBLE ON THE BASIS OF INFRARED RISK}

\author{
Bandura V. PhD, professor, Yaroshenko L. PhD, docent \\ Vinnytsia National Agrarian University of Ukraine, Vinnytsia, Ukraine
}

\begin{abstract}
One of the promising areas for the development of the food industry is the expansion of the range and quality of food. In this case, special attention is paid to the safety and quality of raw materials. Sunflower seeds are a valuable raw material for a range of food and feed products.

The freshly harvested sunflower seeds are very resistant to storage, especially at high humidity, temperature and debris. Therefore, seeds should be dried immediately after harvesting and cleaning. Currently, widespread drying of food materials by infrared (IR) radiation. Despite the large amount of scientific literature on drying, including on IR-installations, practical issues of designing infrared dryers have not been worked out. Well-known studies are exclusively private.

The prospects of using infrared drying of freshly harvested sunflower seeds are due to the fact that this drying method is quite high intensity, economical and allows you to maintain the nutrient and seed quality of the seeds. In addition, there is no need to use air as a thermal agent, which significantly reduces the energy consumption of the drying process. Promising in this sense is a combination of infrared heat conduction and active contact of seeds with unheated air, which provides, for example, a vibro boiling layer. The use of infrared heat removal for the drying of sunflower seeds is also facilitated by the black husk color and the relatively small thickness of sunflower seeds, which, under certain regime parameters, can provide infrared rays penetration into the central layers of the nucleus.

The technological features of drying sunflower seeds by means of infrared energy supply are described, and the prospect of vibration monolayer drying of sunflower seed in a trap vibration dryer is substantiated. The specific energy costs are determined for the process of infra-red drying of the product.
\end{abstract}

Keywords: infrareddrying, vibroilotdryer, sunflowerseeds, energy.

Вступ. Одним з перспективних способів сушіння олійного насіння є застосування інфрачервогого опромінення. Техніка зневоднення продуктів і матеріалів значно випереджає теоретичні положення сушіння. Не тільки класична література 3 проблем сушіння, але і спеціальна не дають конкретних рекомендацій 3 проектування установок з електромагнітним підведенням енергії. Разом 3 тим, саме такі установки активно прогресують і характеризуються серйозними проблемами в моделюванні. Тому поки єдиним надійним шляхом їх дослідження є експеримент.

Аналіз проблематики та літературних джерел. Насіння високоолійного соняшнику надійно зберігається, якщо вологість їх не перевищує $7 \%$, а температура знижена до $10{ }^{\circ} \mathrm{C}$ і нижче. При вологості вище 


\section{Одеська начіональна академія харчових технологій ІННОВАЦЙНН ЕНЕРГОТЕХНОЛОГІЇ ХАРЧОВИХ ВИРОБНИЦТВ}

критичної та температурі $20 \ldots .25{ }^{\circ} \mathrm{C}$, в насипі насіння починається бурхливий розвиток мікроорганізмів, інтенсивно відбуваються гідролітичні і окисні процеси. Такі процеси призводять до швидкого погіршення якості насіння соняшнику як олійної сировини. Навіть кілька годин зберігання щойно зібраного насіння високоолійного соняшнику вологістю вище критичної приводить до масового самозігрівання і псування, що робить неможливим отримання високоякісної олії [1].

На сучасному етапі, з виникненням фермерських та орендних підприємств, створилися нові вимоги до техніки, що використовується для післязбиральної обробки i, зокрема, сушіння зернових і олійних культур. Фермери прагнуть не тільки виростити хороший урожай, але і довести його до стану, придатного для реалізації або тривалого зберігання. Вартість і терміни виконання послуг з сушіння на елеваторах не влаштовує фермерів. Особливі проблеми виникають при сушінні елітного насіннєвого зерна, яке випускається порівняно малими партіями, вимагає суворого ощадного режиму сушіння і не допускає перемішування 3 іншими сортами. При посівах зернових в фермерському господарстві від 100 до 300 га наявність сушарки 3 інфрачервоним підведенням енергії, сприятиме підвищенню ефективності технологічного процесу післязбиральної обробки насіння.

Експериментально встановлено [2, 3], що інфрачервоні промені проникають в глиб матеріалу, причому глибина проникнення зменшується зі збільшенням довжини хвилі (при зниженні температури випромінювача). Для вологих матеріалів проникність інфрачервоних променів мала. Проходження променів на деяку глибину всередину тіла приводить до аномального розподілу температури всередині нього. При нагріванні або сушінні капілярно-пористих тіл, такими іє олійне насіння, температура максимальна не на поверхні, а на деякій глибині [4]. Починаючи від поверхні, температура спочатку підвищується, досягає максимального значення на невеликій глибині, а потім знижується.

Обгрунтування різних причин, що викликають аномальний розподіл температури по товщині матеріалу при ІЧ- опроміненні, викладено в роботах А.В Ликова [2], С.Г. Ільясова [4], А.С. Гінзбурга [5], І.А. Рогова [6], та ін. Це явище пояснюється наступними комплексом причин: поглинання проникаючого ІЧвипромінювання в матеріал на деяку глибину та переходом його там в теплоту; втратою енергії (випромінюванням, конвекцією, теплопровідністю) відкритою поверхнею в навколишнє середовище; явищем теплового ковзання - циркуляцією повітря в порах під дією температурного градієнта; явищем молекулярної течії дифузіі газу в мікрокапілярах у напрямку температурного градієнта; витратами тепла на пароутворення при випаровуванні вологи в поверхневому шарі.

Питання впровадження інноваційних рішень, що спрямовані на зменшення питомих витрат енергії обладнанням з ІЧ-енергопідведенням для підготовки зернових матеріалів до зберігання або до переробки, споживання чи до згодовування надзвичайно важливі Але їх вирішення ускладнюється відсутністю уніфікованих підходів до синтезу математичної моделі тепломасообмінних процесів і мінливістю взаємопов'язаних кінетичних коефіцієнтів в розроблених аналітичних моделях, що залежать від фізичних і хімічних властивостей взаємодіючих речовин і енергій [7].

Енергоефективність інфрачервоних сушарок безпосередньо пов'язана 3 характеристиками поглинання матеріалу, що визначає економічну доцільність сушарки [8]. ІЧ-випромінювання проникає безпосередньо у внутрішній шар матеріалу без нагрівання навколишнього повітря. Враховуючи відстань між джерелом нагріву і матеріалом, швидкість повітряного потоку і температуру, а також швидкість матеріалу (якщо безперервна ІЧ-сушарка) може істотно впливати на енергетичну ефективність.

Якщо підсумувати та проаналізувати експерименти інших дослідників, можна зробити висновок, що збільшення рівня потужності інфрачервоного випромінювання призводить до скорочення часу сушіння, тоді як збільшення швидкості повітря призводить до збільшення часу сушіння та споживання енергії. Підвищуючи швидкість повітря, поверхневий шар стає прохолодним і необхідний більш тривалий час сушіння. Таким чином, швидкість повітря повинна регулюватися для забезпечення кращих результатів. Рівень потужності інфрачервоного випромінювання також слід регулювати, оскільки збільшення потужності може призвести до втрати якості. Крім того, існують інші фактори, які не були розглянуті дослідниками такі як вплив вібрації на процес сушіння в ІЧ сушарках.

Дослідниками інституту холоду та біотехнологій Санкт-Петербургу [9] проведено дослідження процесу сушіння насіння соняшнику насіннєвого фонду інфрачервоним випромінюванням виділеної довжини хвилі при досягненні заданого вмісту вологи і температури, що не перевищує 44- $46{ }^{\circ} \mathrm{C}$ на поверхні шару оброблюваного матеріалу залежно від висоти шару продукту, густини теплового потоку, відстані від інфрачервоного випромінювача до продукту. 3 аналізу експериментальних кривих видно, що вологість насіння соняшнику протягом усього процесу сушіння зменшується з плином часу за лінійним законом, при цьому температура в центрі шару продукту не перевищує 44- $46^{\circ}$ С. Проте дослідники [9] не застосовували вібраційний вплив переміщення зерна вздовж сушарки.

В роботі [10] теоретично обгрунтовано процеси радіаційно-конвективного тепломасообміну між усіма визначальними об’єктами всередині вібраційної сушарки з ІЧ-енергопідведенням. На основі теплового і матеріального балансів визначено рівняння, які описують основні динамічні характеристики режиму

Наукові праці, Том 83, випуск 1 Scientific Works, Volume 83, Issue 1 
сушіння олієвмісного матеріалу в безперервно діючій ІЧ-сушарці. У зв’язку з тим, що точного аналітичного розв'язку представленої математичної моделі у вигляді системи диференціальних рівнянь у частинних похідних не існує. Запропоноване наближене рішення дозволяє ідентифікувати залежності розподілу температури і вологовмісту зернового та олієвмісного матеріалу за довжиною сушарки для будь-якого моменту часу.

Авторами в роботі [11] запропоновано технології адресної доставки енергії для інтенсифікації тепломасопереносу при переробці харчової сировини. У основі запропонованих гіпотез - хвильові технології комбінованої електромагнітної і вібраційної дії. Обгрунтовано механізми, ефекти і математичні моделі бародифузії і дії вібраційних полів. Запропоновано числа хвильової подібності, на основі яких узагальнені бази експериментальних даних по сушінню.

Були проведені численні дослідження по тонкошаровому сушінню харчових продуктів, використовуючи різні способи обробки і способи сушіння: соя [12], подрібнений рис [13], гібридне рисове насіння [14], але дуже мало інформації для вібраційного інфрачервоного сушіння насіння соняшнику.

Нами проводились дослідження на розробленій вібротерморадіаційній моношарній сушарці «осцилюючого» нагрівання. Тому при подальших дослідженнях, для зменшення температури прогрівання частинок продукції, при не меншій величині зменшення іiі вологості, було запропоновано $[15,16]$ використовувати «осцилююче» нагрівання інфрачервоним промінням, при якому періоди нагрівання чергуються із періодами обдування холодним повітрям, а для збудження коливань використано електромеханічний дебаланснийвібропривод.

Мета роботи - дослідження кінетики технологічного процесу сушіння зерна соняшнику шляхом підведення інфрачервоного опромінення у вібролотковій моносушарці.

Матеріали і методи дослідження. В експериментальних дослідженнях використовували контрольновимірювальну апаратуру, сучасні методики та прилади, серед яких і розробки авторів. Для аналітичного дослідження використовувалися програмні пакети: MathCAD, Excel. Методики дослідження зразків проводилися в лабораторіях і відповідали стандартам.

Дослідно-промисловий зразок вібраційної машини для сушіння насіння соняшнику, спроектований i виготовлений у лабораторії автоматизації технологічних процесів Вінницького національного аграрного університету дозволяє у широких межах регулювати температуру сушіння (від 20 до $\left.180{ }^{\circ} \mathrm{C}\right)$, швидкість повітря змінюється в межах 0,5...2,5 м/с, амплітуду коливань вібролотка (від 0,5 до 6 мм). Принципова схема такої сушильної машини приведена на рис. 1.

Технічна характеристика лабораторної вібраційної сушарки

Продуктивність, кг/год.

Потужність електронагрівачів, кВт

Потужність віброприводу лотків, кВт

\section{Потужність вентилятора, кВт}

\section{Амплітуда коливань вібролотка, мм}

Частота обертів приводного електродвигуна, об/хв.

Температура у термокамері, ${ }^{\circ} \mathrm{C}$

Maca, кг

Габаритні розміри, мм
110

6,0 ;

1,0 ;

\section{0,5}

0-6;

910;

20-180;

230;

1400x600x3000;

Машина складається із закритого кожухом корпусу 1, на площадках 2 якого за допомогою пружних елементів 3 встановлено термічний 4 і колосниковий 5 лотки. Робоча доріжка термічного лотка 4 виготовлена із жаростійкої листової сталі. Робоча доріжка колосникового лотка утворюються повздовжніми вертикальними смужками 7, що приварені до кронштейнів 8, таким чином, щоб між ними був повздовжній зазор $\delta=$ $1,5 \ldots 2$ мм. По середині кожного лотка змонтовано віброприводи, що містять по два відцентрових віброзбуджувачі, встановлені із боків лотка.

Кожний відцентровий віброзбуджувач містить вал із дебалансними вантажами 9, який за допомогою еластичної муфти 10 з'єднаний з приводним асинхронним електродвигуном 11. Причому у кожному віброприводі електродвигуни 11 з'єднані таким чином, щоб при підключенні до мережі їх ротори обертались назустріч один одному. Вали 3 дебалансними вантажами 9 встановлені на підшипниках паралельно один до одного під кутом $\beta$ до площин робочих доріжок лотків. Над поверхнями термічних лотків 4 закріплені термогенератори 12 (ІЧ-випромінювачі). Зверху і з боків термічний лоток 4 закритий термоізоляцією 13. Над початком термічного лотка 4 закріплена завантажувальна горловина 14, а в кінці крильчатка 15, під початком колосникового лотка 5 розміщено нагнітальний патрубок вентилятора 16, а вище поверхні колосникового лотка 6 - вивідний патрубок 17 з регулювальним шибером 18. В кінці колосникового лотка 5 встановлено приймальний бункер 19.

Наукові праці, Том 83, випуск 1 


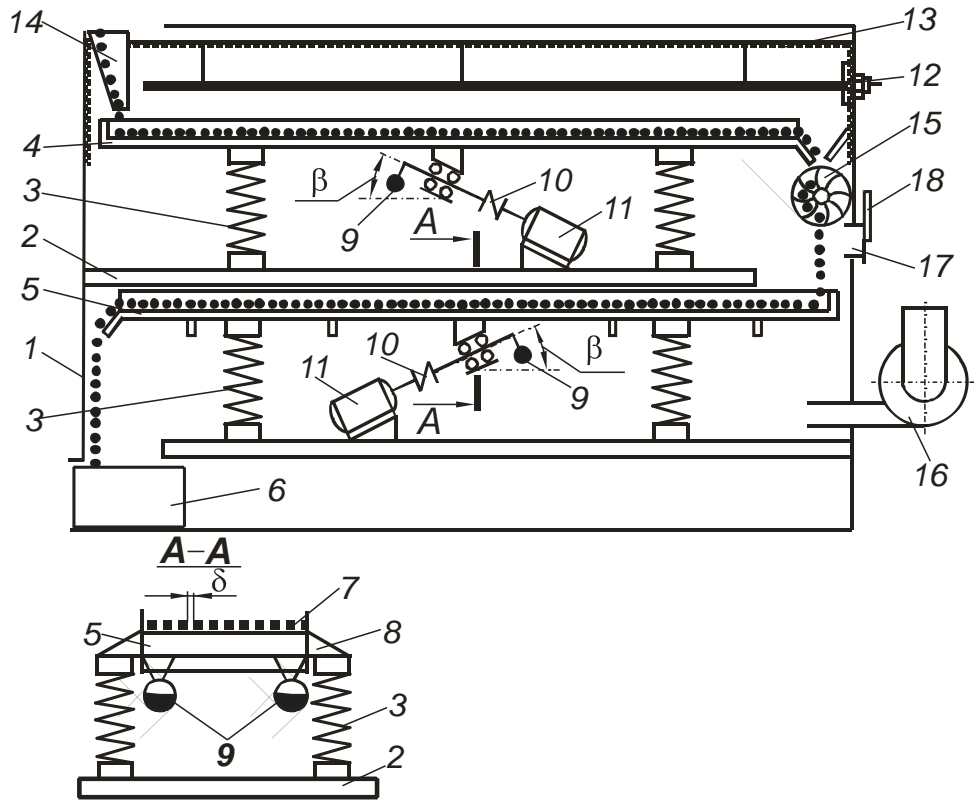

Рис. 1. Схема лабораторної інфрачервоної моношарної вібросушарки:

1 - корпус; 2 - площадка; 3 - пружні елементи; 4 - термічний лоток; 5 - колосниковий лоток;

6 - приймальний бункер; 7 - повздовжні вертикальні смужки; 8 - кронштейн; 9 - дебалансний вантаж; 10 - еластична муфта; 11- електродвигун; 12 - термогенератори; 13 - термоізоляція; 14 - завантажувальна горловина; 15 - крильчатка; 16 - вентилятор; 17 - вивідні патрубки; 18 - регулювальний шибер.

Машина працює таким чином. При включенні приводних електродвигунів 11, їх ротори починають обертатись назустріч один одному у кожному віброприводі, що призводить до динамічної синхронізації їх обертання, внаслідок чого генеруються поступальні коливання лотків 4 і 5 під кутом $\beta$ до площин їх робочих доріжок. Сипка продукція подається через завантажувальну горловину на поверхню лотків, де під дією коливань розподіляється моношаром. Під дією коливань лотків між їх поверхнею і частинками сипкої продукції виникає асиметрія сил тертя, що призводить до виникнення направленого руху частинок сипкої продукції (вібротранспортування) вздовж поверхні лотків. При цьому точки поверхні лотків коливаються відносно деякого центру без направленого руху в цілому за період одного коливання. За допомогою зміни статичних моментів дебалансних вантажів 9 відносно осі обертання, встановлюється режим вібротранспортування із неперервним підкиданням частинок сипкої продукції під час їх переміщення вздовж лотків. Неперервне підкидання частинок продукції призводить до їх хаотичного провертання при переміщенні вздовж термічних лотків 4, над якими знаходяться термогенератори $12 \mathrm{i}$ сприяє їх рівномірному опроміненню з усіх боків інфрачервоним промінням, що призводить до інтенсивного, швидкого і рівномірного прогрівання насіння соняшнику.

Після проходження термічного лотка, прогріта продукція (насіння соняшнику) подається через барабанну крильчатку 15 на колосниковий лоток 5 , де обдувається атмосферним повітрям від вентилятора 16 . При цьому, неперервне хаотичне підкидання і провертання частинок продукції, також покращує рівномірність їх обдування повітрям, що призводить до порушення рівноважного стану вологи у частинках продукції, коли тиск парів води в них стає більшим за парціальний тиск парів води у повітрі, внаслідок чого волога починає інтенсивно випаровуватись $[15,16]$.

Оброблена продукція після проходження колосникового лотка 5 подається у приймальний бункер 19. Барабанна крильчатка 15 запобігає доступу потоку холодного повітря від вентилятора 16 у камеру високої температури над термічним лотком 4 і водночас дозволяє просипання продукції 3 термічного лотка 4 на колосниковий 5.

Інтенсивність повітряних потоків регулюється шибером 18. Швидкість вібротранспортування сипкої продукції, а отже час ії знаходження на поверхні лотків регулюється шляхом зміни статичних моментів дебалансних вантажів 9 відносно осі їх обертання, або кута $\beta$. Оскільки інфрачервоне випромінювання термогенератора 12 дозволяє створити дуже інтенсивний тепловий потік, що сприяє швидкому прогріванню частинок продукції, а процес випаровування із них вологи вимагає більшого проміжку часу, то швидкість вібротранспортування на колосниковому лотку 5 встановлюється більшою.

Інфрачервоний нагрівальний пристрій складався з 24 інфрачервоних лампи на 250 Вт (OSRAM, Словаччина), що розташовані у сушарці в шаховому порядку. Відстань між лампами, при якій досягається най-

Наукові праці, Том 83, випуск 1 Scientific Works, Volume 83, Issue 1 
більша рівномірність енергетичної опроміненності поверхні висушуваного матеріалу була 0,12 м. Лампи працюють від джерела живлення 220 В. ІЧ лампи можна розташовувати на відстані $5 \ldots 15$ см від поверхні лотка.

Вологість насіння соняшнику визначається висушуванням проб до постійної маси. Проби відбирались до і після проходження ІЧ- опромінення та обдування повітрям.

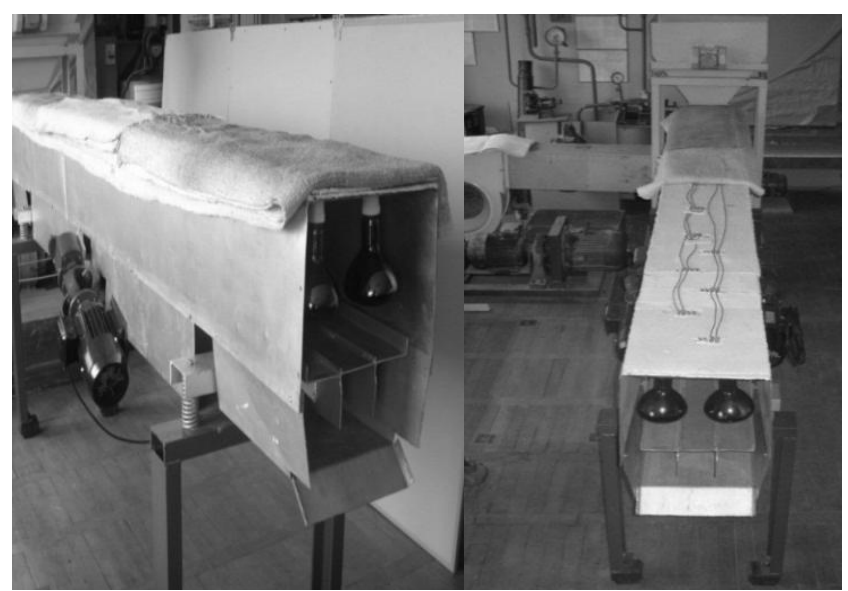

Рис.2. Фото експериментальної вібролоткової інфрачервоної сушарки (крильчатка, вивідні патрубки, регулювальний шибер на фото не показані)

Бункер завантаження продукції забезпечений шлюзом, який регулює товщину моношару продукту на лотку в межах $7 \ldots 22$ мм залежно від розмірів зерна та швидкості його руху по лотку.

Інтенсивність інфрачервоного випромінювання змінювалася шляхом зміни відстані між лампами і поверхнею прийому. Також для досягнення необхідних рівномірних рівнів інтенсивності інфрачервоного випромінювання згадану відстань регулювали вручну, змінюючи висоту підвісу корпусу лампи. Для забезпечення однорідності інфрачервоного випромінювання над соняшником попередні вимірювання проводили перед основними випробуваннями.

Маса зерна визначалась електронними вагами ТВЕ-0,21-0,01. Температура продукту вимірювались дистанційно пірометром Laserliner. Зміна маси зерен до проведення дослідження і після визначала масу вилученої вологи.

В дослідах фіксувалось тривалість процесу, температура і маса соняшника на початку та в кінці обробки. Питома маса матеріалу (g) показує масу (m) продукту на одиницю поверхні обробки (F), а питома потужність - ІЧ- енергію, яка витрачається на $1 \mathrm{~m}^{2}$ оброблюваної поверхні.

Діапазон дослідження процесу ІЧ - сушіння

Таблиия 1

\begin{tabular}{|c|c|c|c|c|}
\hline Сировина & $\begin{array}{lr}\text { Питома } & \text { поту- } \\
\text { жність } & \text { ІЧ, } \\
\text { кВт/м } & \end{array}$ & $\begin{array}{l}\text { Середня темпера- } \\
\text { тура насіння, } \\
T,{ }^{\circ} \mathrm{C}\end{array}$ & 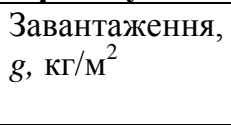 & $\begin{array}{l}\text { Тривалість } \\
\text { процесу } \tau, \text { хв }\end{array}$ \\
\hline $\begin{array}{l}\text { Насіння соня- } \\
\text { шнику }\end{array}$ & $3,0 \ldots 6,0$ & $34 \ldots 44$ & $4,11 \ldots 8,22$ & $30 \ldots 60$ \\
\hline
\end{tabular}

Досліди проводилися при температурі повітря у приміщенні $20^{\circ} \mathrm{C}$, відносній вологості повітря у приміщенні 65 \%. Вивчався вплив потужності підведеної енергії на середню швидкість процесу сушіння. Досліди проводились при швидкості руху зерна по лотку 0,025 м/с, i питомому завантаженні 4,11 кг/м². Кількість питомої вологи визначали за початковою і кінцевою вологістю соняшника. Швидкість сушіння розраховувалась за кількостю питомої вологи i часу, протягом якого на насіння соняшнику впливало ІЧвипромінювання.

Під час сушіння, температура поверхні насіння контролювалася і була меншою за $60{ }^{\circ} \mathrm{C}$. Масова витрата вхідного повітря забезпечувалась вентилятором і контролювалась за допомогою електричного інвертора (N50-007SF, Корея). Швидкість повітря для всіх дослідів вимірювали за допомогою ТЕSTO Анемометр 425 (Німеччина) з точністю $\pm 0,03 \mathrm{~m} / \mathrm{c}$. Швидкість повітря змінюється в межах $0,5 \ldots 2,5 \mathrm{M} / \mathrm{c}$ шляхом регулювання оборотів двигуна вентилятора.

Початкова вологість насіння соняшника була рівна $17 \pm 0,5 \%$. Всього було проведено 34 експерименти 3 комбінацій трьох рівнів інфрачервоного випромінювання (3000, 4000, 6000 Вт/м²) і вібрації (24 ГЦ)). Щоб виміряти зміну вологості в процесі сушіння, вібролоткову сушарку через проміжок часу в 7 хв зупиняли і відбирали проби.

Наукові праці, Том 83, випуск 1 Scientific Works, Volume 83, Issue 1 
Експериментальні дослідження. Обговорення результатів. Зниження витрат на сушіння насіння соняшнику як енергоємного процесу, поряд з підвищенням інтенсивності вологовіддачі розглядається як найважливіше завдання при розробці нових технологій сушіння і конструкцій сушарок. Будь-яка модернізація сушарки може бути визнана досить ефективною, якщо досягнуте скорочення питомих енерговитрат (при обов'язковому збереженні якості продукту).

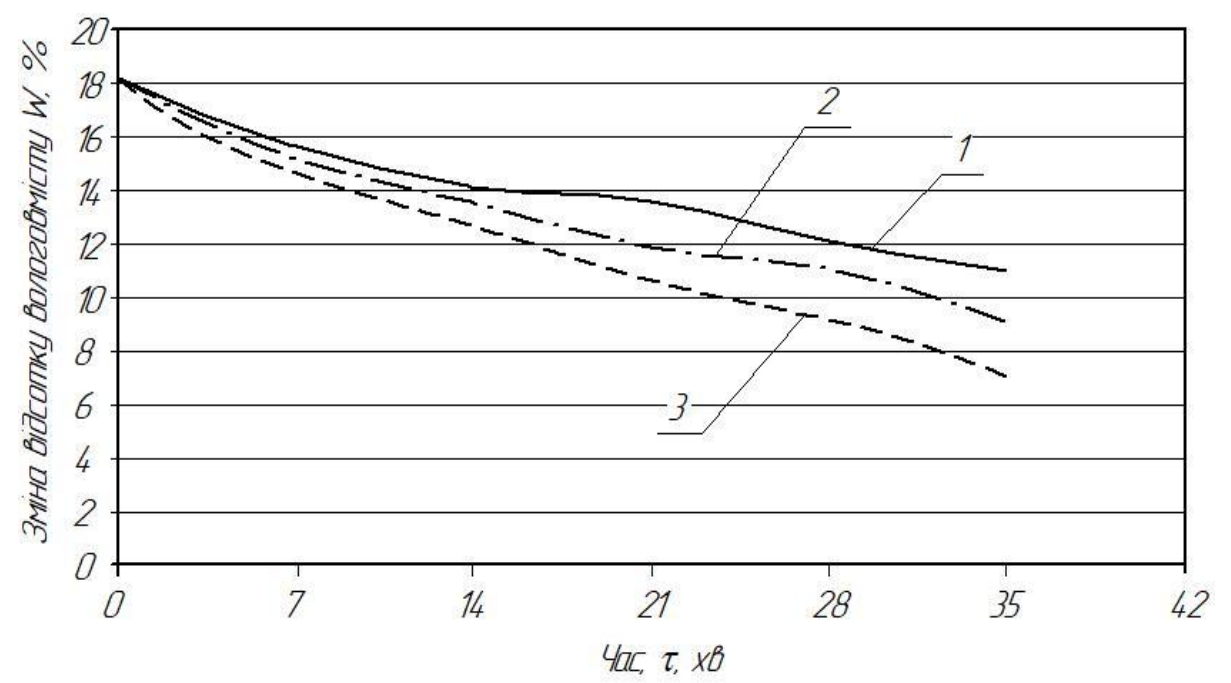

Рис. 3 - Вплив питомої потужності на кінетику сушіння: де, $1-\mathrm{N}=3000 \mathrm{Bт} / \mathrm{M}^{2} ; 2-\mathrm{N}=4000 \mathrm{BT} / ; 3-\mathrm{N}=6000 \mathrm{BT} / \mathrm{M}^{2}$.

Параметрами ІЧ-сушіння насіння соняшнику, що рекомендуються, лампами "OSRAM" на підставі проведених експериментальних досліджень слід вважати: висоту підвішування ІЧ-випромінювача при сушінні зерна $h=0,1 \mathrm{~m} ; \mathrm{t}_{\min }=35{ }^{\circ} \mathrm{C}$ до $\mathrm{t}_{\max }=43{ }^{\circ} \mathrm{C}$. При збільшенні питомої потужності у 2 рази (рис.3) час процесу сушіння зменшується пропорційно. Час процесу сушіння до відносної вологості продукту у 6-7\% займає $35 . .60$ хвилин.

На основі проведених досліджень запропонована принципова схема вібролоткової моношарної сушарки переміжного інфрачервоного нагрівання $[17,18]$. Випробування ІЧ вібросушарки проводилось на базі комплексу обладнання, у якому для кінцевого сушіння насіння соняшнику використовувалась шахтна сушарка БРИГ ЗШ-400 продуктивністю 400 кг/год при встановленій потужності електронагрівачів та приводу вентилятора 35 кВт, потужність нагрівачів, віброприводу та вентилятора ІЧ вібросушарки, становила 7,5 кВт при продуктивності роботи 110 кг/год. При порівнянні витрат економія електроенергії на сушіння в розробленій ІЧ сушарці складає 1,2 рази.

Економія електроенергії здійснюється за рахунок того, що у ІЧ вібросушарці не нагрівається повітря, як це здійснюється у конвективних сушарках, а нагрівається безпосередньо саме насіння, тому втрати тепла з відпрацьованим теплим повітрям відсутні, а вони є найбільшими при роботі конвективних зерносушарок. Сушильна установка зберігає усі переваги лабораторної інфрачервоної моношарної вібросушарки, що описана вище. При цьому максимальна температура прогрівання частинок продукції у 1,5 - 2 рази менша при більших межах зменшення їх вологості. Це дозволяє здійснювати якісний обробіток продукції при менших теплових витратах.

Однак, оскільки вихідна вологість сипучої продукції може коливатись у дуже широких межах, то для регулювання швидкості вібротранспортування сипучої продукції вздовж вібролотків, а отже часу їх обробки на кожному лотку, авторами [19] запропоновано регулювати параметри коливань лотка шляхом зміни величини і частоти коливань вимушуючої сили для забезпечення енергоощадного резонансного режиму роботи вібросушарки.

\section{Висновки.}

1. Виконано комплексні експериментальні дослідження впливу режимних параметрів (питомого навантаження і потужності) на кінетику ІЧ-сушіння зерна соняшнику у вібраційній лабораторній інфрачервоній моношарнійвібросушарці.

2. При збільшенні питомої потужності у 2 рази час процесу сушіння зменшується пропорційно. Не спостерігалося розтріскування лушпиння. 
3. Параметрами ІЧ-сушіння зерна соняшнику, що рекомендуються, лампами "OSRAM" на підставі проведених експериментальних досліджень слід вважати: висоту підвішування ІЧ-випромінювача при сушінні зерна $h=0,1 \mathrm{~m} ; \mathrm{t}_{\min }=35^{\circ} \mathrm{C}$ до $\mathrm{t}_{\max }=44^{\circ} \mathrm{C}$.

4. Вібраційна моношарна сушарка переміжного інфрачервоного нагрівання дозволяє зменшити питомі енерговитрати приблизно у 1,2...1,3 рази, порівняно з конвекційною сушаркою.

\section{References}

1. Stankevich, G. M. (2003) Sovremennaya sushka semyan podsolnechnika - zalog ikh kachestva isokhrannosti. Olíyno-zhiroviykompleks, 2, 25-28.

2. Lykov, A. V. (1968) Teoriya sushki. M.:Energiya, 470.

3. Burdo, O. G. (2007) Evolyutsiya sushil'nykh ustanovok . Odessa, 368.

4. Il'yasov, S.G. Krasnikov, V.V. (1978) Fizicheskiye osnovy infrakrasnogo oblucheniya pishchevykh produktov. M.: Pishchevaya promyshlennost', 359.

5. Ginzburg, A. S. Vasil'yeva, A. S. (1965) Kombinirovannaya sushka semyan podsolnechnika v kipyashchem sloye i infrakrasnymi luchami. Khraneniye i pererabotka zerna; TSINTI Goskomiteta zagotovok SSSR, 4, 11-16. 272.

6. Rogov, I. A. (1988) Elektrofizicheskiye metody obrabotki pishchevykh produktov. M.: Agropromizdat,

7. Kotov, B. I. Bandura, V. M. Kalinichenko R. A. (2018) Matematychne modelyuvannya ta identyfikatsiya teplomasoperenosu v roslynnomu dyspersnomu materiali pry sushinni i nahrivanni elektromahnitnym polem. Enerhetyka i avtomatyka, 6, 35-50.

8. Pawar, S. B. Thorat, B. N. (2011) Infrared drying of alumina-silicatemineral cake. Drying Technology, 29(7), 819-824.

9. Demidov, A. S. Voronenko, B.A. Demidov, S.F. (2011) Sushka semyan podsolnechnika infrakrasnym izlucheniyem. Novyye tekhnologii, 3, 25-30.

10. Bandura, V. Kalinichenko, R. Kotov, B.SpirinA. (2018) Theoretical rationale and identification of heat and mass transfer processes in vibration dryers with IR-energy supply. Eastern-European Journal of Enterprise Technologies, 4/8(94), 50-58.

11. Burdo, O., Bandura, V., Zykov, A., Zozulyak, I., Levtrinskaya, J., Marenchenko, E. (2017) Development of wave technologies to intensify heat and mass transfer processes. Eaestern-European Jurnal of Enterprise Tehnologies, 4/11(88), 34-42.

12. Ranjbaran, M. Zare, D. (2012) A new approach for modeling of hot air-microwave thin layer drying of soybean. Electron. J. Pol. Agric. Univ, 15 (3),1-11.

13. Tanaka, F. Yamashita, K., Tanaka, A., Tanaka, F., Hamanaka, D., Uchino, T. (2014) High temperature drying characteristics of crushed rice for animal feed. Eng. Agr. Environ. Food, 7 (3),133-138.

14. Hasan, A. M. Bala, B. K. Rowshon, M. K. (2014)Thin layer drying of hybrid rice seed. Eng. Agr. Environ. Food, 7 (4), 169- 175.

15. Pat. \# 45431 UkraYina, MPK F26B5/00. SposIbvIbromonosharnogosushInnya/ L. V. Yaroshenko; zayavnik ta patentovlasnik VInnitskiy derzhavniy sIlskogospodarskiy Institut. \# 98073470; zayavl. 02.07. 1998; opubl. 15.04. 2002, Byul. \# 4, 3 s.Goncharevich, I. F. (1972) Dinamika vibratsionnogo transportirovaniya. M.: Nauka, 212.

16. Yaroshenko, L.V. (2011) Víbratsíyna shakhtna susharka. Vibratsii v tekhnike i tekhnologiyakh, 1 (17), $44-46$.

17. Pat. \# 105075 S2 UkraYina, MPK V65G 27/24. SposIb stabIlIzatsIYi shvidkostI gorizontalnogo vIbrotransportuvannya $\mathrm{v}$ adaptivnih vIbratsIynih tehnologIchnih mashinah. L. V. Yaroshenko, R.V. Chubik; zayavnik ta patentovlasnik VInnitskiy natsIonalniy agrarniy unIversitet. \# 201206929; zayavl. 06.06. 2012; opubl. 10.04. 2014, Byul. \# 23, 5 s.

18. Pat. \# 116418 S2 UkraYina, MPK V06V 1/16. Kerovaniy vIbroprivod napryamlenoYi dIYi zI sparenimi debalansami. L. V. Yaroshenko, R.V. Chubik, V.M. Bandura, V.V. Tomchuk, N.M. Zraylo; zayavnik ta patentovlasnik VInnitskiy natsIonalniy agrarniy unIversitet. \# 201609034; zayavl. 25.08. 2016; opubl. 12.03. 2018, Byul. \# 4, 5 s.

Отримано в редакцію 02.05.2019

Прийнято до друку 22.06.2019
Received 02.05.2019

Approved 22.06.2019 